Article

\title{
Entacapone Treatment Modulates Hippocampal Proteins Related to Synaptic Vehicle Trafficking
}

\author{
Dae Young Yoo ${ }^{1,2} \oplus$, Hyo Young Jung ${ }^{1}\left(\mathbb{D}\right.$, Woosuk Kim ${ }^{1,3}$, Kyu Ri Hahn ${ }^{1}$, Hyun Jung Kwon ${ }^{4}$, \\ Sung Min Nam ${ }^{5}$, Jin Young Chung ${ }^{6}\left(\mathbb{D}\right.$, Yeo Sung Yoon ${ }^{1}$, Dae Won Kim ${ }^{4, *}$ \\ and In Koo Hwang 1,*(D) \\ 1 Department of Anatomy and Cell Biology, Research Institute for Veterinary Science, College of Veterinary \\ Medicine, Seoul National University, Seoul 08826, Korea; dyyoo@sch.ac.kr (D.Y.Y.); \\ hyoyoung@snu.ac.kr (H.Y.J.); tank3430@hallym.ac.kr (W.K.); hkinging@snu.ac.kr (K.R.H.); \\ ysyoon@snu.ac.kr (Y.S.Y.) \\ 2 Department of Anatomy, College of Medicine, Soonchunhyang University, Cheonan 31151, Korea \\ 3 Department of Biomedical Sciences, Research Institute for Bioscience and Biotechnology, Hallym University, \\ Chuncheon 24252, Korea \\ 4 Department of Biochemistry and Molecular Biology, Research Institute of Oral Sciences, College of Dentistry, \\ Gangneung-Wonju National University, Gangneung 25457, Korea; donuts25@gwnu.ac.kr \\ 5 Department of Anatomy, School of Medicine and Institute for Environmental Science, Wonkwang University, \\ Iksan 54538, Korea; namvet1@wku.ac.kr \\ 6 Department of Veterinary Internal Medicine and Geriatrics, College of Veterinary Medicine, \\ Kangwon National University, Chuncheon 24341, Korea; jychung77@gmail.com \\ * Correspondence: kimdw@gwnu.ac.kr (D.W.K.); vetmed2@snu.ac.kr (I.K.H.)
}

Received: 6 November 2020; Accepted: 10 December 2020; Published: 18 December 2020

check for updates

\begin{abstract}
Entacapone, a reversible inhibitor of catechol-O-methyl transferase, is used for patients in Parkinson's disease because it increases the bioavailability and effectiveness of levodopa. In the present study, we observed that entacapone increases novel object recognition and neuroblasts in the hippocampus. In the present study, two-dimensional electrophoresis (2-DE) and matrix-assisted laser desorption/ionization time-of-flight (MALDI-TOF) mass spectrometry were performed to compare the abundance profiles of proteins expressed in the hippocampus after entacapone treatment in mice. Results of 2-DE, MALDI-TOF mass spectrometry, and subsequent proteomic analysis revealed an altered protein expression profile in the hippocampus after entacapone treatment. Based on proteomic analysis, 556 spots were paired during the image analysis of 2-DE gels and 76 proteins were significantly changed more than two-fold among identified proteins. Proteomic analysis indicated that treatment with entacapone induced expressional changes in proteins involved in synaptic transmission, cellular processes, cellular signaling, the regulation of cytoskeletal structure, energy metabolism, and various subcellular enzymatic reactions. In particular, entacapone significantly increased proteins related to synaptic trafficking and plasticity, such as dynamin 1, synapsin I, and Munc18-1. Immunohistochemical staining showed the localization of the proteins, and western blot confirmed the significant increases in dynamin I (203.5\% of control) in the hippocampus as well as synapsin I (254.0\% of control) and Munc18-1 (167.1\% of control) in the synaptic vesicle fraction of hippocampus after entacapone treatment. These results suggest that entacapone can enhance hippocampal synaptic trafficking and plasticity against various neurological diseases related to hippocampal dysfunction.
\end{abstract}

Keywords: entacapone; hippocampus; proteomics; synaptic trafficking; mouse 


\section{Introduction}

The hippocampus, one of the major components of the limbic system, plays essential roles in the integration of spatial memory [1] and aversive contextual memory [2]. In addition, the hippocampus is a neurogenic region, including the subventricular zone, and new neurons are associated with object recognition performance in the hippocampus [3]. Several studies have demonstrated that damage to the hippocampus causes impairment in object recognition performance [4,5], and novel object recognition is inhibited by blocking neurogenesis in the hippocampus [6]. The hippocampus receives synaptic inputs from various brain regions, including the entorhinal cortex, hypothalamus, amygdala, ventral tegmental area, and locus coeruleus $[7,8]$. Among these connections, the dopaminergic system is very important because dopamine receptors are expressed in the hippocampus and dopaminergic transmission is associated with learning, memory, and synaptic plasticity $[9,10]$.

Entacapone [(2E)-2-cyano-3-(3,4-dihydroxy-5-nitrophenyl)- $N, N$-diethylprop-2-enamide] is known as a reversible inhibitor of catechol-O-methyl transferase (COMT), and entacapone increases the bioavailability and effectiveness of levodopa [11]. Several in vitro studies have shown that entacapone decreases oxidative stress [12] and can quench oxidative radicals $\left(\mathrm{ONOO}^{-}\right.$and $\left.\mathrm{HOCl}^{-}\right)$, and effectively ameliorates $\mathrm{H}_{2} \mathrm{O}_{2}$-induced cell death in human umbilical vein endothelial cells [13]. In addition, entacapone decreases aggregation of $\alpha$-synuclein and $\beta$-amyloid [14]. In in vivo studies, oral administration of entacapone is promptly absorbed, reaches its maximal concentration at $0.7-1.82 \mathrm{~h}$ after treatment, and is eliminated by $4 \mathrm{~h}$ after treatment $[15,16]$. Treatment with $30-100 \mathrm{mg} / \mathrm{kg}$ entacapone reduces COMT activity [17], increases the formation of 3,4-dihydroxyphenylacetic acid in the striatum [18], and decreases the efflux of homovanillic acid [17], although entacapone does not show any penetration efficacy in the blood-brain barrier [19]. In a previous study, we demonstrated that entacapone treatment significantly increased novel object recognition memory and hippocampal neurogenesis by upregulating brain-derived neurotrophic factor, tyrosine kinase receptor $\mathrm{B}$, and phosphorylated cAMP response element-binding protein [20].

However, to date, there are no considerable studies on the effects of entacapone on protein expression in the hippocampus. In the present study, therefore, we investigated protein expression following entacapone treatment using two-dimensional D-gel electrophoresis (2DE) followed by matrix-assisted laser desorption/ionization time-of-flight mass spectrometry (MALDI-TOF MS) in the hippocampus. In addition, we validated the significantly altered proteins related to synaptic vesicle trafficking in the hippocampus.

\section{Materials and Methods}

\subsection{Chemicals}

Alfaxalone and xylazine were obtained from Careside (Seongnam, South Korea) and Bayer Korea (Seoul, South Korea), respectively. Buffers or reagents used in proteomic and immunohistochemical study such as urea, thiourea, 3-[(3-cholamidopropyl) dimethylammonio]-1-propanesulfonate, dithioerythritol, Tris buffer, sodium dodecyl sulfate (SDS), glyceride, acrylamide, Tributylphosphine, ammonium bicarbonate, acetonitrile, ammonium bicarbonate, paraformaldehyde, phosphate buffer. Syn-PER Reagent and nitrocellulose membranes were purchased from Thermo Fisher Scientific (Waltham, MA, USA) and Pall Crop (East Hills, NY, USA), respectively, Antibodies specific for dynamin 1, Munc18-1, and synapsin I purchased from Abcam (Cambridge, UK) and normal goat serum and FITC-conjugated goat anti-rabbit IgG were acquired from Vector Lab. (Burlingame, CA, USA) and Jackson ImmunoResearch (West Grove, PA, USA), respectively.

\subsection{Experimental Animals and Entacapone Treatment}

Male seven-week-old C57BL/6J mice $(n=60)$ were obtained from Orient Bio (Sungnam, South Korea). Animals were housed in a specific pathogen-free facility at the Seoul National University College of Veterinary Medicine under adequate temperature, humidity, and light/dark cycle. Experimental 
protocols for animal experiments were approved by the Institutional Animal Care and Use Committee (Approval no. SNU-130730-1).

\subsection{Entacapone Treatment}

After acclimating for 1 week, mice ( $n=30$ in each group) were divided into a vehicle-treated group and a $50 \mathrm{mg} / \mathrm{kg}$ entacapone-treated group. Entacapone was dissolved in $0.9 \%$ physiological saline, and vehicle or entacapone was administered orally to the mice once a day for 21 days using a feeding needle.

\subsection{Protein Preparation for $2 D E$}

Two hours after the last entacapone or vehicle treatment, mice were deeply anesthetized with a mixture of $75 \mathrm{mg} / \mathrm{kg}$ alfaxalone and $10 \mathrm{mg} / \mathrm{kg}$ xylazine. Hippocampal tissues, which were isolated from the brains of vehicle- or entacapone-treated mice ( $n=20$ in each group), were processed as described in previous studies [21,22]. Suspensions were sonicated 5 times for $10 \mathrm{~s}$ and were centrifuged at $45,000 \mathrm{rpm}$ for $45 \mathrm{~min}$. Proteins in the supernatants were quantified using a 2D Quant kit (GE Healthcare, Uppsala, Sweden).

\subsection{Analysis of 2-DE Gels}

As previously described [21,22], 2-DE was performed. Briefly, from each group, $1 \mathrm{mg}$ of hippocampal protein was rehydrated in the sample buffer (7 M urea, $2 \mathrm{M}$ thiourea, 4.5\% 3-[(3-cholamidopropyl) dimethylammonio]-1-propanesulfonate, $100 \mathrm{mM}$ dithioerythritol, $40 \mathrm{mM}$ Tris, $\mathrm{pH} 8.8$ ), and applied to immobilized pH 3-10 non-linear gradient strips (Amersham Biosciences, Uppsala, Sweden). Isoelectric focusing was performed at $80,000 \mathrm{Vh}$. The strips were reduced and alkylated in Tributylphosphine equilibration buffer (6 M urea, $2 \%$ sodium dodecyl sulfate (SDS), $30 \mathrm{mM}$ Tris, $20 \%$ glycerol, $2.5 \%$ acrylamide solution, and $5 \mathrm{mM}$ Tributylphosphine), and then proteins were separated in the second dimension using SDS-polyacrylamide gel electrophoresis (SDS-PAGE) (9-16\%) at $40 \mathrm{~mA}$ for $5 \mathrm{~h}$. Proteins were fixed in $40 \%$ methanol and $5 \%$ phosphoric acid for $1 \mathrm{~h}$, and the gels were stained with Coomassie brilliant blue G 250 solution overnight. The gels were destained with ultrapure distilled water. After fixation, the gels were scanned using a GS710 scanning densitometer (Bio-Rad, Richmond, CA, USA), and the results were converted into electronic files. The data were analyzed with the Image Master Platinum 5.0 image analysis program (Amersham Biosciences).

\subsection{Trypsin Digestion of Master Gels}

Protein spots of interest were picked from the preparative gel into 1.5-mL Eppendorf tubes. The gel pieces were washed with distilled water and shaken in $50 \mathrm{mM}$ ammonium bicarbonate and acetonitrile (6:4) until Coomassie brilliant blue G 250 was washed out. Proteins in the spots (100 ng per spot) were digested on ice with $5 \mu \mathrm{L}$ trypsin (Promega, Southhampton, UK) in $50 \mathrm{mM}$ ammonium bicarbonate for $45 \mathrm{~min}$, and then incubated at $37^{\circ} \mathrm{C}$ for $12 \mathrm{~h}$.

\subsection{Protein Identification Using MALDI-TOF MS}

MALDI-TOF MS was performed as described previously [21,22]. Tryptic peptides were desalted and purified using the Poros 10 R2 resin (Applied Biosystems, Foster City, CA, USA) and Oligo R3 (Applied Biosystems). Mass spectra of peptides were obtained using the 4800 MALDI-TOF analyzer (Applied Biosystems) in reflection/delayed extraction mode with an accelerating voltage of $20 \mathrm{kV}$, and the data were summed from 500 laser pulses. The spectrum was calibrated with trypsin auto-digested peaks (m/z: 842.5090 and 2211.1046), and monoisotopic peptide masses were obtained with the Data Explorer 4.4 (PerSeptive Biosystems Inc., Framingham, MA, USA). A mass range of $800-4000 \mathrm{~m} / \mathrm{z}$ was used with 1000 shots per spectrum. At the end of the macro process, raw data were generated about the centroid mass, resolution, height, and $\mathrm{S} / \mathrm{N}$ ratio of each peak. These data were 
converted to an Excel file and were used for MASCOT (Matrix Science, London, UK) search to identify peptide sequences that were present in the protein sequence database NCBInr (mouse). Protein scores higher than 67 were considered significant $(p<0.05)$.

\subsection{Validation of Selected Proteins}

\subsubsection{Western Blot Analyses}

To validate the proteins related to synaptic vehicles selected from 2-DE and MALDI-TOF MS, mice ( $n=5$ per group) were euthanized with a mixture of alfaxalone and xylazine. The left and right hippocampal tissues were quickly removed from the brain and left hippocampi were homogenized in a buffer, as described previously [21,22], while the right hippocampi were treated with Syn-PER Reagent and homogenized. The homogenate was centrifuged at $15,000 \times g$ for $20 \mathrm{~min}$ to obtain the synaptosome fraction. Briefly, protein-transferred nitrocellulose membranes were sequentially treated with rabbit anti-dynamin 1 (1:500, Abcam), rabbit anti-Munc18-1 (1:1000), and rabbit anti-synapsin I (1:500). Data were normalized to $\beta$-actin levels as demonstrated in previous studies $[21,22]$.

\subsubsection{Immunohistochemistry}

To visualize the proteins related to synaptic vehicles selected from 2-DE and MALDI-TOF MS, mice ( $n=5$ per group) were anesthetized with a mixture of alfaxalone and xylazine and perfused transcardially with $0.9 \%$ saline and $4 \%$ paraformaldehyde in phosphate buffer. Serially sectioned tissues (30- $\mu \mathrm{m}$ thickness) were used for immunohistochemical staining for dynamin 1 , synapsin I, and Munc18-1 between 1.7 and $2.3 \mathrm{~mm}$ caudal to the bregma, referring to the mouse atlas by Paxinos and Franklin [23]. Briefly, three sections, $150 \mu \mathrm{m}$ apart, were selected and sequentially treated with $5 \%$ normal goat serum (Vector Lab.), primary antibodies, and FITC-conjugated goat anti-rabbit IgG (1:200; Jackson ImmunoResearch). The optical density of dynamin 1, synapsin I, and Munc18-1 was calculated using ImageJ software (National Institutes of Health, Bethesda, MD, USA) as described previously [20]. Briefly, the density of immunoreactive structures was measured based on 256 gray scale and the sum of density of pixel $\times$ pixel number was calculated in three sections per animal. The relative optical density was expressed as percentages of the vehicle-treated group.

\subsection{Statistical Analysis}

Results are shown as mean \pm standard deviation. Results were statistically analyzed with Student's $t$-test using SPSS (IBM, Armonk, NY, USA). A value of $p<0.05$ was considered statistically significant.

\section{Results}

\subsection{Proteomic Profiles Changed by Entacapone Treatment}

To elucidate significantly altered protein expression caused by entacapone treatment, proteomic analysis was performed using the hippocampi of vehicle- and $50 \mathrm{mg} / \mathrm{kg}$ entacapone-treated mice. Figure 1 shows representative 2-DE gel images with separated protein spots obtained from the hippocampi of vehicle- and entacapone-treated mice. In both groups, more than 600 protein spots were detected on each 2-DE gel, and every spot was located within the ranges of $\mathrm{pH}$ 3-10 and 10-200 kDa. In this study, 556 spots were paired during the image analysis of 2-DE gels (Figure 1). Image analysis revealed that the expression of 106 protein spots had more than a 2.0-fold difference, and 76 proteins, except for unnamed and clustered proteins, were identified with MALDI-TOF MS and the subsequent MASCOT search. Identified proteins were classified according to the following criteria: (1) proteins involved in vesicular trafficking and endocytosis (Table 1); (2) proteins involved in cellular signaling and various cellular processes including cell cycle, mitosis, and differentiation (Table 2); (3) proteins involved in the regulation of cell structure and morphology (Table 3); (4) proteins 
involved in carbohydrate and energy metabolism (Table 4); and (5) proteins with other enzymatic activities (Table 5).
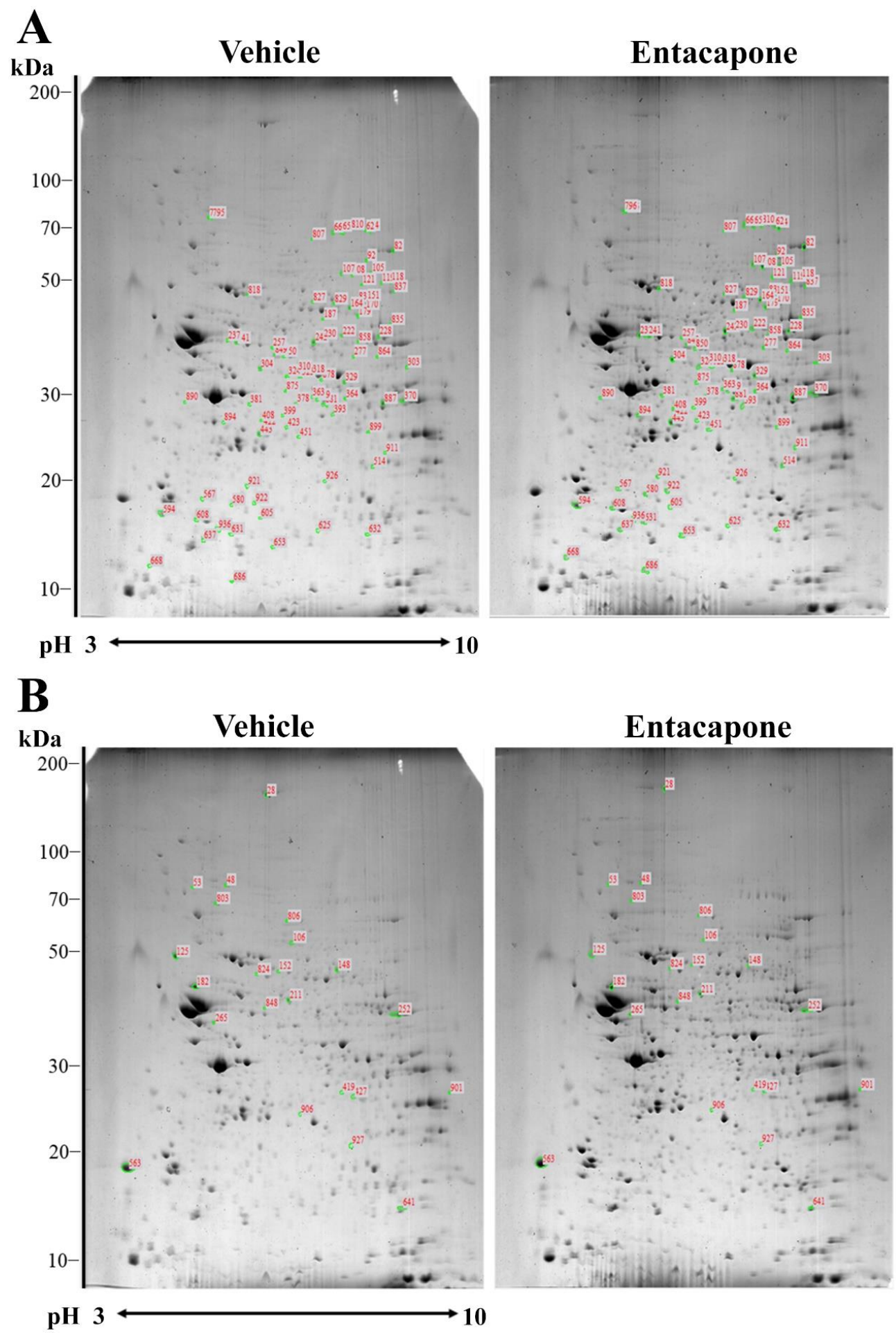

Figure 1. Two-dimensional electrophoresis (2-DE) gel pattern of hippocampal proteins extracted from the vehicle- and entacapone-treated groups. The spots labeled with red numbers indicate that the expression level of corresponding proteins is upregulated (A) or downregulated (B) more than two-fold following entacapone treatment. Proteins extracted from both groups were applied to immobilized pH 3-10 non-linear gradient strips, and then were separated with 9-16\% sodium dodecyl sulfate (SDS)-polyacrylamide gels. Gels were stained with Coomassie brilliant blue G 250 solution. 


\subsection{Proteins Responsible for Vesicular Trafficking and Endocytosis}

First, treatment with entacapone induced expressional changes in proteins that regulate vesicular trafficking and endocytosis. Dynamin $1(+4.0-,+2.7-$, and +25.9 -fold change in spots no. 62,65 , and 810, respectively) was identified in three spots (Figure 2). Expression of synapsin I (+20.2-fold change in spot no. $105 ;-4.0$-fold change in spot no. 106) (Figure 3 ) and synapsin II (+2.6-fold change) were significantly changed. The expression levels of the following proteins responsible for endocytosis, protein transport, vesicular trafficking, and neurotransmitter release also changed significantly: $N$-ethylmaleimide sensitive fusion protein $(\mathrm{NSF},+2.1$-fold), vesicle-fusing ATPase (+3.1-fold), Munc18-1 (+4-fold) (Figure 4), Eps15 homology (EH) domain containing protein 3 (+2.3-fold), Rab GDP dissociation inhibitor beta $(+2.2$-fold), adaptin ear-binding coat-associated protein 1 ( +2.5 -fold), and synaptosomal associated protein 25 (SNAP-25) (+2.5-fold) (Table 1).

Table 1. Differentially expressed proteins related to vesicular trafficking after entacapone treatment in the hippocampus.

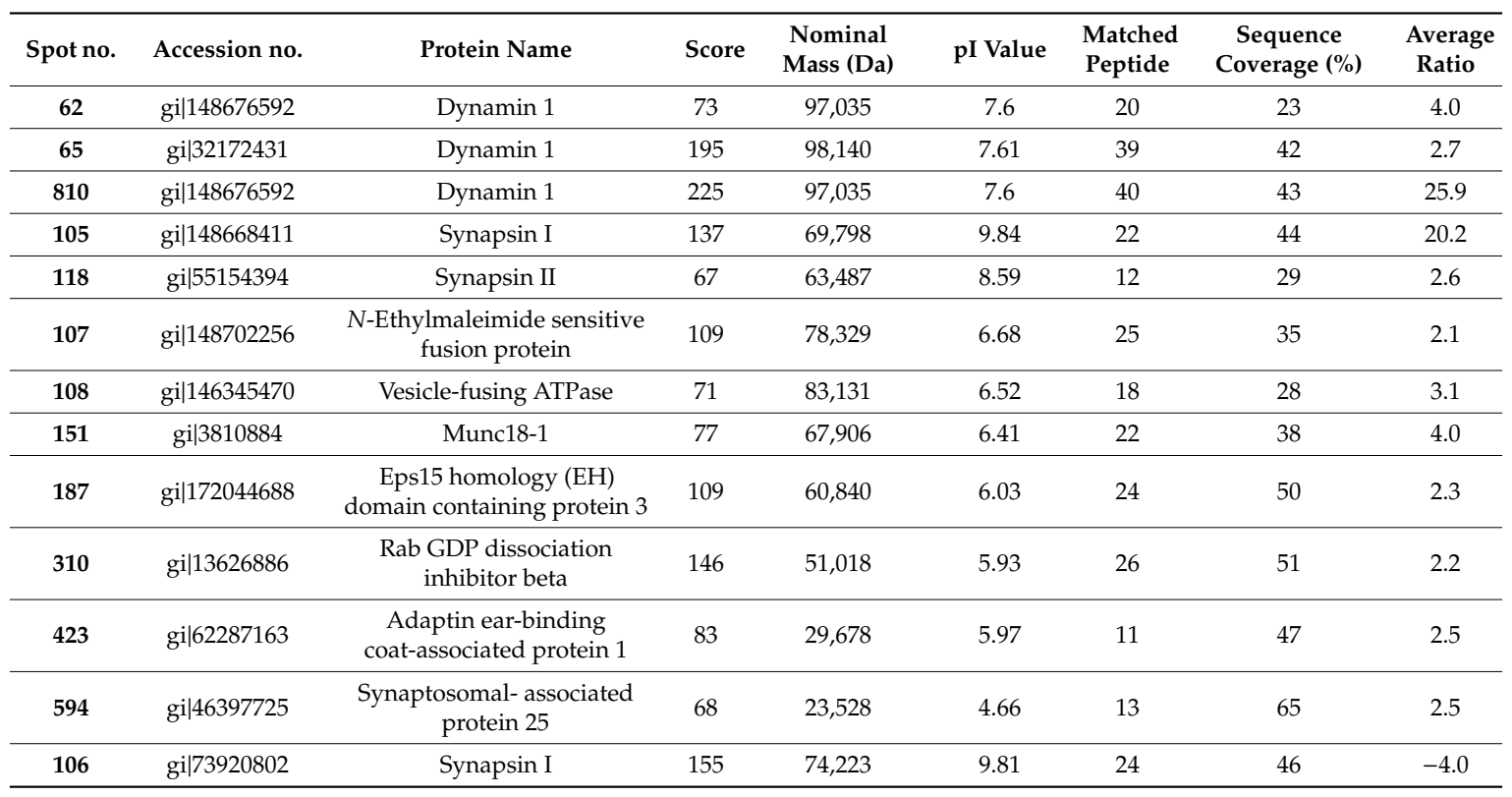

\subsection{Proteins Responsible for Cellular Signaling and Processes}

We identified proteins that are implicated in cellular signaling and diverse cellular processes, such as the cell cycle, mitosis, differentiation, and transformation. The expression levels of the following proteins were changed: transformation/transcription domain-associated protein (+3.9-fold), nuclear receptor-binding SET-domain protein $1(+4.7$-fold), COP9 signalosome complex subunit 4 (+2.6-fold), guanine nucleotide-binding protein alpha 11 subunit (+2.8-fold), fizzy/cell division cycle 20 related 1 (+2.0-fold), valosin-containing protein $(-2.9$-fold $)$, protein tyrosine phosphatase $(-2.2$-fold), and tyrosine 3-monooxygenase/tryptophan 5-monooxygenase activation protein (-2.1-fold) (Table 2). 
Table 2. Differentially expressed proteins related to cell signaling and processes after entacapone treatment in the hippocampus.

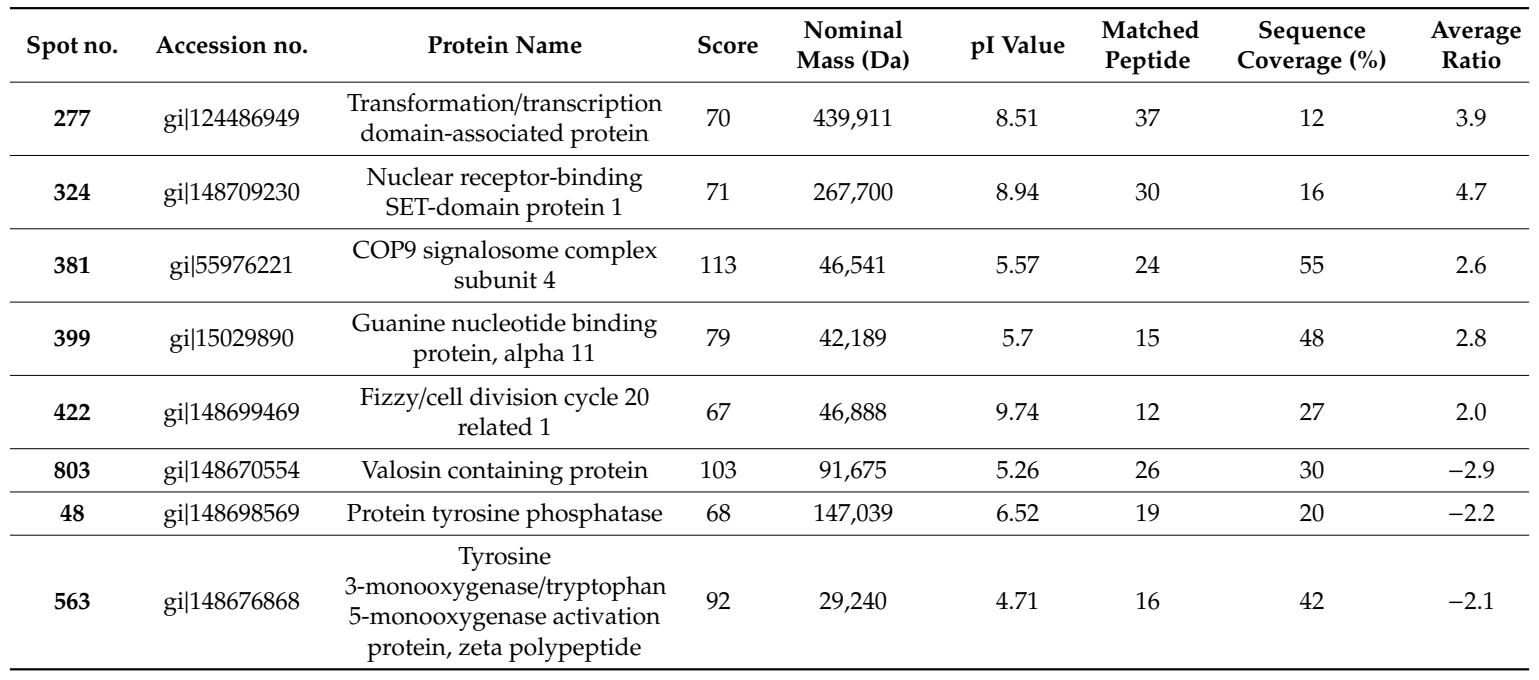

\subsection{Proteins Responsible for the Regulation of Cell Structure and Morphology}

Proteins that regulate the morphology and cytoskeletal organization, and thus affect neuritogenesis and cell migration, were identified. The expression levels of the following proteins changed significantly: titin isoform N2-B (+2.1-fold), dihydropyrimidinase-related protein 1 and 2 (+2.1- and -3.7-fold in spots no. 179 and 152, respectively), tubulin alpha-1C chain (-2.9-fold), tubulin beta-4A chain (+4.7-fold), tetratricopeptide repeat protein 23 isoform $2(+2.0$-fold), septin 2 (+2.0-fold), actin monomer-binding protein twinfilin-1 (+2.3-fold), formin-like protein 1 (+3.0-fold), actin-related protein $2 / 3$ complex subunit $2(+2.0$-fold), axonemal dynein heavy chain $5(+2.0-$ fold $)$, myosin-7 $(+2.4$-fold $)$, spectrin alpha chain (-2.1-fold), and neurofilament light polypeptide (-5.8-fold) (Table 3$)$.

Table 3. Differentially expressed proteins related to cell structure and morphology after entacapone treatment in the hippocampus.

\begin{tabular}{|c|c|c|c|c|c|c|c|c|}
\hline $\begin{array}{l}\text { Spot } \\
\text { No. }\end{array}$ & Accession no. & Protein Name & Score & $\begin{array}{l}\text { Nominal } \\
\text { Mass (Da) }\end{array}$ & pI Value & $\begin{array}{l}\text { Matched } \\
\text { Peptide }\end{array}$ & $\begin{array}{c}\text { Sequence } \\
\text { Coverage }(\%)\end{array}$ & $\begin{array}{l}\text { Average } \\
\text { Ratio }\end{array}$ \\
\hline 92 & gi|77812699 & Titin isoform N2-B & 76 & $3,004,899$ & 6.24 & 85 & 4 & 2.1 \\
\hline 237 & gi|146345529 & Tubulin beta-4A chain & 119 & 50,010 & 4.78 & 22 & 46 & 4.7 \\
\hline 242 & gi|270309132 & $\begin{array}{l}\text { Tetratricopeptide repeat } \\
\text { protein } 23 \text { isoform } 2\end{array}$ & 67 & 50,391 & 8.36 & 13 & 34 & 2.0 \\
\hline 849 & gi|9957546 & Septin 2 & 94 & 49,050 & 5.74 & 18 & 39 & 2.0 \\
\hline 393 & gi|30421118 & $\begin{array}{l}\text { Actin monomer-binding } \\
\text { protein twinfilin } 1\end{array}$ & 67 & 40,368 & 6.33 & 10 & 38 & 2.3 \\
\hline 451 & gi|67460975 & Formin-like protein 1 & 69 & 122,724 & 5.62 & 20 & 21 & 3.0 \\
\hline 514 & gi|110825706 & $\begin{array}{l}\text { Actin-related protein } 2 / 3 \\
\text { complex subunit } 2\end{array}$ & 74 & 34,450 & 6.84 & 14 & 47 & 2.0 \\
\hline 850 & gi|81871557 & Myosin 7 & 70 & 223,539 & 5.59 & 27 & 20 & 2.4 \\
\hline 28 & gi|295054271 & Spectrin alpha chain & 87 & 283,519 & 5.2 & 36 & 18 & -2.1 \\
\hline 125 & gi|116283387 & $\begin{array}{l}\text { Neurofilament light } \\
\text { polypeptide }\end{array}$ & 140 & 57,848 & 4.78 & 24 & 40 & -5.8 \\
\hline 152 & gi|94730376 & $\begin{array}{l}\text { Dihydropyrimidinase-related } \\
\text { protein } 2 \text { (CRMP2) }\end{array}$ & 78 & 62,638 & 5.95 & 14 & 26 & -3.7 \\
\hline 848 & gi|55977482 & Tubulin alpha-1C chain & 76 & 50,562 & 4.96 & 16 & 48 & -2.9 \\
\hline
\end{tabular}




\subsection{Proteins Regulating Energy Metabolism}

Proteins implicated in carbohydrate and energy metabolism were identified from spots. The expression levels of the following metabolic enzymes were altered: mitochondrial aconitase 2 (+5.1-fold), fumarate hydratase 1 (+2.3-fold), alpha-enolase $(+2.2-$ and +2.1 -fold in spots no. 318 and 323, respectively), mitochondrial precursor of 3-hydroxyisobutyryl-CoA hydrolase (+2.7-fold), $3^{\prime}\left(2^{\prime}\right), 5^{\prime}$-bisphosphate nucleotidase 1 (+3.3-fold), UMP-CMP kinase (+2.3-fold), muscle isoform M1 of pyruvate kinase (+2.6-fold), transketolase (+2.4-fold), alpha subunit of the $\mathrm{H}^{+}$transporting ATP synthase of the mitochondrial F1 complex ( -2.4 -fold), dihydrolipoamide S-acetyltransferase precursor (-2.2-fold), calcium-binding protein 39 (+2.7-fold), and pyrophosphatase 2 (-2.1-fold) (Table 4).

Table 4. Differentially expressed proteins related to energy metabolism after entacapone treatment in the hippocampus.

\begin{tabular}{|c|c|c|c|c|c|c|c|c|}
\hline $\begin{array}{l}\text { Spot } \\
\text { No. }\end{array}$ & Accession no. & Protein Name & Score & $\begin{array}{l}\text { Nominal } \\
\text { Mass (Da) }\end{array}$ & pI Value & $\begin{array}{l}\text { Matched } \\
\text { Peptide }\end{array}$ & $\begin{array}{c}\text { Sequence } \\
\text { Coverage (\%) }\end{array}$ & $\begin{array}{c}\text { Average } \\
\text { Ratio }\end{array}$ \\
\hline 82 & gi|63101587 & Aconitase 2 , mitochondrial & 184 & 86,185 & 8.08 & 30 & 41 & 5.1 \\
\hline 318 & gi|13637776 & Alpha-enolase & 98 & 47,453 & 6.37 & 20 & 50 & 2.2 \\
\hline 323 & gi|13637776 & Alpha-enolase & 79 & 47,453 & 6.37 & 15 & 38 & 2.1 \\
\hline 408 & gi|46396056 & $\begin{array}{c}3^{\prime}\left(2^{\prime}\right), 5^{\prime} \text {-Bisphosphate } \\
\text { nucleotidase } 1\end{array}$ & 70 & 33,517 & 5.54 & 12 & 43 & 3.3 \\
\hline 653 & gi|23821758 & UMP-CMP kinase & 74 & 22,379 & 5.68 & 12 & 61 & 2.3 \\
\hline 835 & gi|359807367 & $\begin{array}{l}\text { Pyruvate kinase, muscle } \\
\text { isoform M1 }\end{array}$ & 75 & 58,461 & 6.69 & 21 & 40 & 2.6 \\
\hline 824 & gi|16580128 & $\begin{array}{c}\text { Dihydrolipoamide } \\
\text { S-acetyltransferase precursor }\end{array}$ & 69 & 59,389 & 5.71 & 20 & 31 & -2.2 \\
\hline 906 & gi|148680234 & Pyrophosphatase (inorganic) 2 & 68 & 35,754 & 8.8 & 12 & 47 & -2.1 \\
\hline
\end{tabular}

\subsection{Proteins with Various Enzymatic Activities}

Proteins with various enzymatic activities were identified from spots. Expression levels of the following enzymes changed: isoaspartyl peptidase/L-asparaginase (+3.6-fold), mGSTA4-4 (+2.6-fold), leukotriene-A4 hydrolase (+2.0-fold), Ccdc80 protein (+2.3-fold), glutamate dehydrogenase 1 (+4.0-fold), protein phosphatase methylesterase $1(+3.2$-fold), cytoplasmic aspartate aminotransferase (+2.0-fold), monoglyceride lipase (+2.2-fold), pyridoxal phosphate phosphatase (PLPP, +2.2 -fold), and carbonyl reductase [NADPH] 3 (+2.0-fold) (Table 5). 
Table 5. Differentially expressed proteins related to enzyme activity after entacapone treatment in the hippocampus.

\begin{tabular}{|c|c|c|c|c|c|c|c|c|}
\hline $\begin{array}{l}\text { Spot } \\
\text { No. }\end{array}$ & Accession no. & Protein Name & Score & $\begin{array}{l}\text { Nominal } \\
\text { Mass (Da) }\end{array}$ & pI Value & $\begin{array}{l}\text { Matched } \\
\text { Peptide }\end{array}$ & $\begin{array}{c}\text { Sequence } \\
\text { Coverage }(\%)\end{array}$ & $\begin{array}{l}\text { Average } \\
\text { Ratio }\end{array}$ \\
\hline 119 & gi|81875980 & $\begin{array}{c}\text { Isoaspartyl } \\
\text { peptidase/L-asparaginase }\end{array}$ & 69 & 32,385 & 7.56 & 12 & 37 & 3.6 \\
\hline 632 & gi|6137391 & mGSTA4-4 & 74 & 25,428 & 7 & 14 & 60 & 2.6 \\
\hline 827 & gi|341941138 & Leukotriene-A4 hydrolase & 105 & 69,634 & 5.98 & 22 & 39 & 2.0 \\
\hline 829 & gi|118600953 & Ccdc 80 protein & 71 & 57,797 & 10.26 & 14 & 40 & 2.3 \\
\hline 858 & gi|148692928 & Glutamate dehydrogenase 1 & 144 & 54,527 & 7.66 & 24 & 44 & 4.0 \\
\hline 875 & gi|108935875 & $\begin{array}{l}\text { Protein phosphatase } \\
\text { methylesterase } 1\end{array}$ & 69 & 42,628 & 5.67 & 15 & 38 & 3.2 \\
\hline 887 & gi|338817898 & $\begin{array}{c}\text { Aspartate aminotransferase, } \\
\text { cytoplasmic }\end{array}$ & 165 & 46,504 & 6.68 & 21 & 60 & 2.0 \\
\hline 911 & gi|148666837 & Monoglyceride lipase & 82 & 37,330 & 7.77 & 19 & 45 & 2.2 \\
\hline 921 & gi|44888293 & $\begin{array}{l}\text { Pyridoxal phosphate } \\
\text { phosphatase }\end{array}$ & 70 & 31,891 & 5.53 & 13 & 48 & 2.2 \\
\hline 926 & gi|81914662 & $\begin{array}{c}\text { Carbonyl reductase } \\
\text { [NADPH] } 3\end{array}$ & 67 & 31,333 & 6.15 & 11 & 45 & 2.0 \\
\hline
\end{tabular}

\subsection{Validation of Protein Level Changes for Dynamin 1, Synapsin I, and Munc18-1}

To validate the proteins and to visualize the locations of proteins identified with 2-DE and MALDI-TOF MS, we performed western blot analysis and immunohistochemical staining, respectively, for dynamin 1, synapsin I, and Munc18-1 (Figure 2). Dynamin was detected in three different spots in 2-DE (Figure 2A). Western blot analysis showed that dynamin 1 levels in the entacapone-treated group significantly increased to $203.5 \%$ of vehicle-treated group (Figure 2B). Dynamin 1 immunoreactivity in vehicle- and entacapone-treated groups was found in the stratum oriens and radiatum of the hippocampal CA1-3 region and outer molecular layer of the dentate gyrus. Dynamin immunoreactivity in the entacapone-treated group was significantly increased to $175.2 \%$ of vehicle-treated group (Figure 2C).

Based on 2-DE, synapsin I spot was larger in entacapone-treated group than in the vehicle-treated group (Figure $3 \mathrm{~A}$ ). Western blot analysis demonstrated that synapsin I protein levels were significantly increased to $148.8 \%$ and $254.0 \%$ of the vehicle-treated group in the whole hippocampus and synaptic vesicle fractions, respectively (Figure 3B). Synapsin I immunoreactivity in vehicle- and entacapone-treated groups was observed in the stratum lucidum of the hippocampal CA3 regions and mossy fibers in the dentate gyrus. Synapsin I immunoreactivity in the entacapone-treated group was significantly increased to $188.8 \%$ of vehicle-treated group (Figure 3C).

Dense Munc18-1 spot was detected in the 2-DE gels of entacapone-treated group compared to that in the vehicle-treated group (Figure 4A). Munc18-1 protein levels based on western blot study did not show any significant differences in the hippocampal homogenates of vehicle- and entacapone-treated groups. However, in the synaptic vesicle fraction, Munc18-1 showed significantly higher levels $(167.1 \%$ of vehicle-treated group) in the entacapone-treated group (Figure 4B). Munc18-1 immunoreactivity in vehicle- and entacapone-treated groups was detected in the stratum lucidum of the hippocampal CA3 regions. Munc18-1 immunoreactivity in the entacapone-treated group was significantly increased to $145.7 \%$ of vehicle-treated group (Figure $4 \mathrm{C}$ ). 
A Vehicle

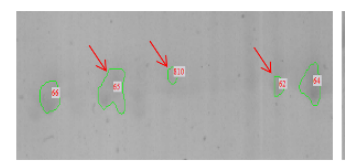

B
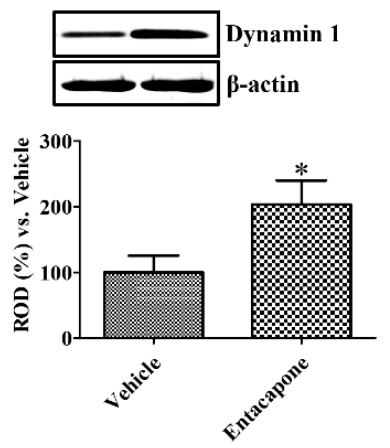

Entacapone C Vehicle
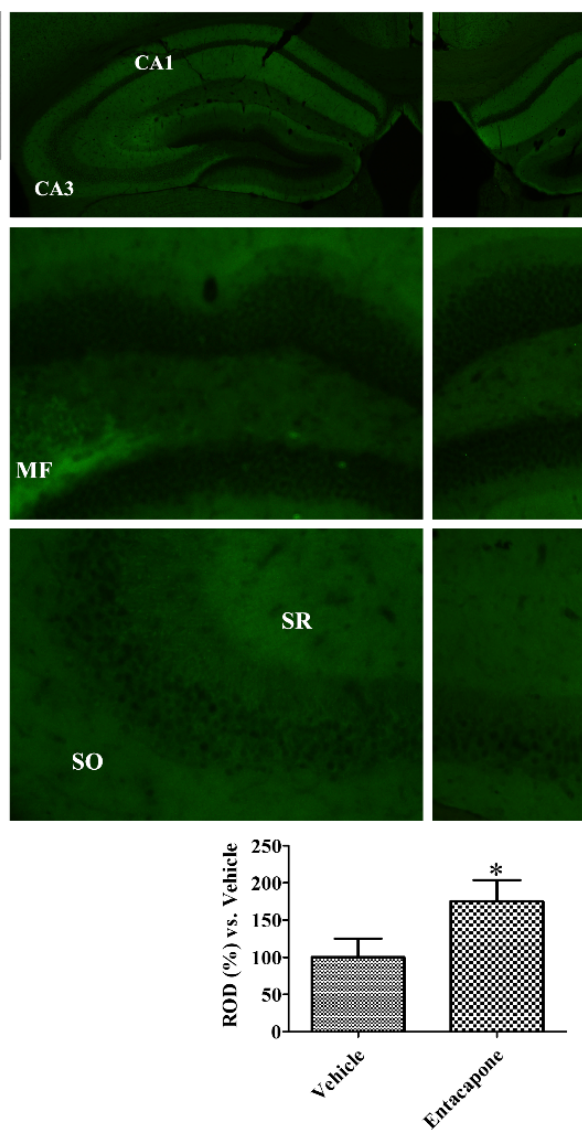

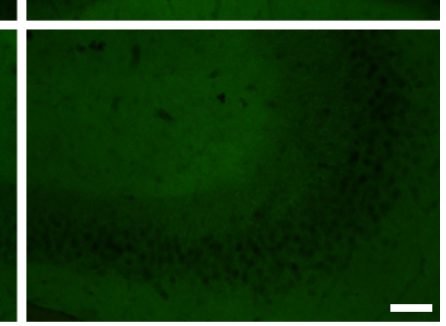

Entacapone
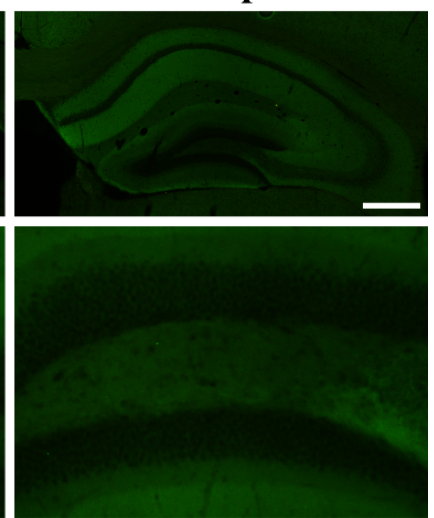

$\hat{v}^{2}$

Figure 2. Dynamin 1 expression in the hippocampus of vehicle- and entacapone-treated groups based on proteomic (A), western blot (B), and immunohistochemical (C) study. Dynamin 1 are detected in three different spots using proteomic analysis and western blot analysis shows significant increases in dynamin 1 protein levels of entacapone-treated group compared to that in the control group. Western blot assays were performed in at least triplicate and bar graph represents the mean \pm standard deviation. Dynamin 1 immunoreactivity is shown in the stratum radiatum (SR) and oriens (SO) of hippocampal CA1-CA3 region and mossy fibers (MFs). Scale bar $=400 \mu \mathrm{m}$ (low magnification), $50 \mu \mathrm{m}$ (high magnification). Three sections, $150 \mu \mathrm{m}$ apart, are selected between 1.7 and $2.3 \mathrm{~mm}$ caudal to the bregma in each animal. Relative optical densities (ROD) are expressed as a percentage of the value of dynamin 1 protein levels and immunoreactivity in the vehicle-treated group ( $n=5$ in each group; ${ }^{*} p<0.05$, significantly different from the vehicle-treated group). The bars indicate the mean values \pm standard deviation. 


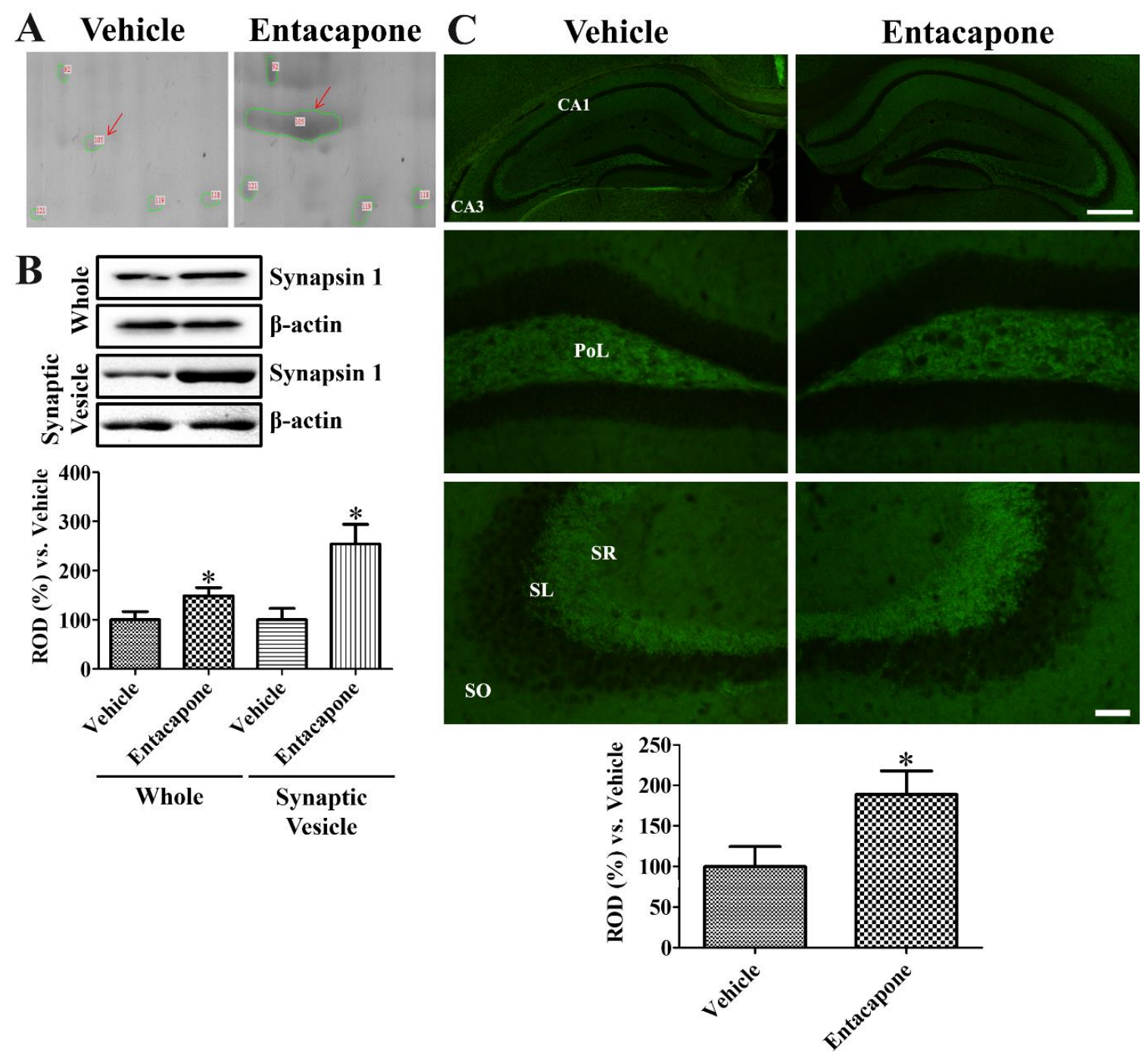

Figure 3. Synapsin I expression in the hippocampus of vehicle- and entacapone-treated groups based on proteomic (A), western blot (B), and immunohistochemical (C) study. Synapsin I spots were detected in proteomic gels and synapsin I protein levels are significantly increased in the hippocampus from whole and synaptic vesicle fractions. Western blot assays were performed in at least triplicate and bar graph represents the mean \pm standard deviation. Synapsin I immunoreactivity is detected in the polymorphic layer $(\mathrm{PoL})$ of dentate gyrus and stratum lucidum (SL) of CA3 region. Scale bar $=400 \mu \mathrm{m}$ (low magnification), $50 \mu \mathrm{m}$ (high magnification). Three sections, $150 \mu \mathrm{m}$ apart, are selected between 1.7 and $2.3 \mathrm{~mm}$ caudal to the bregma in each animal. Relative optical densities (ROD) are expressed as a percentage of the value of synapsin I protein levels and immunoreactivity in the vehicle-treated group ( $n=5$ in each group; ${ }^{*} p<0.05$, significantly different from the vehicle-treated group). The bars indicate the mean values \pm standard deviation. 
A Vehicle Entacapone
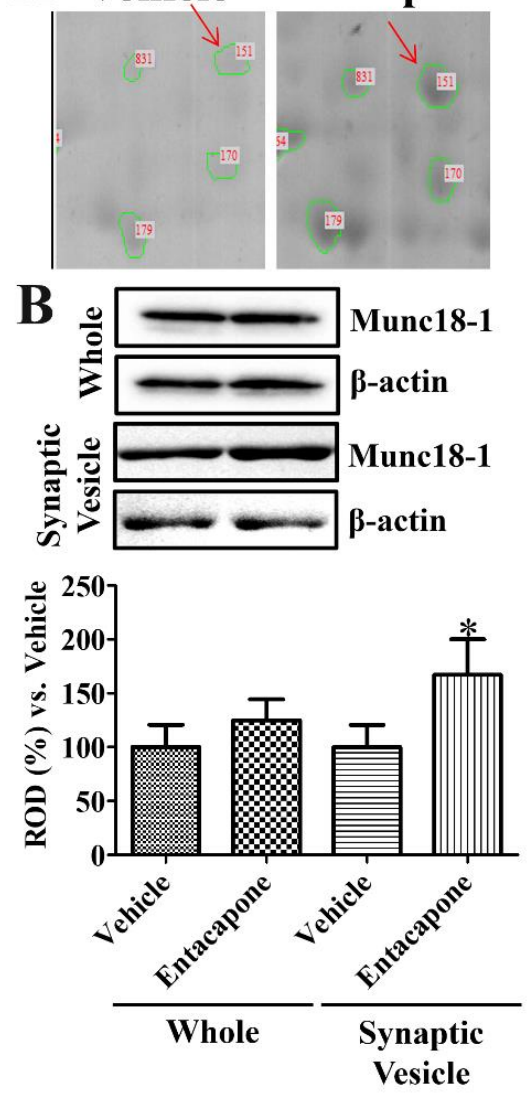
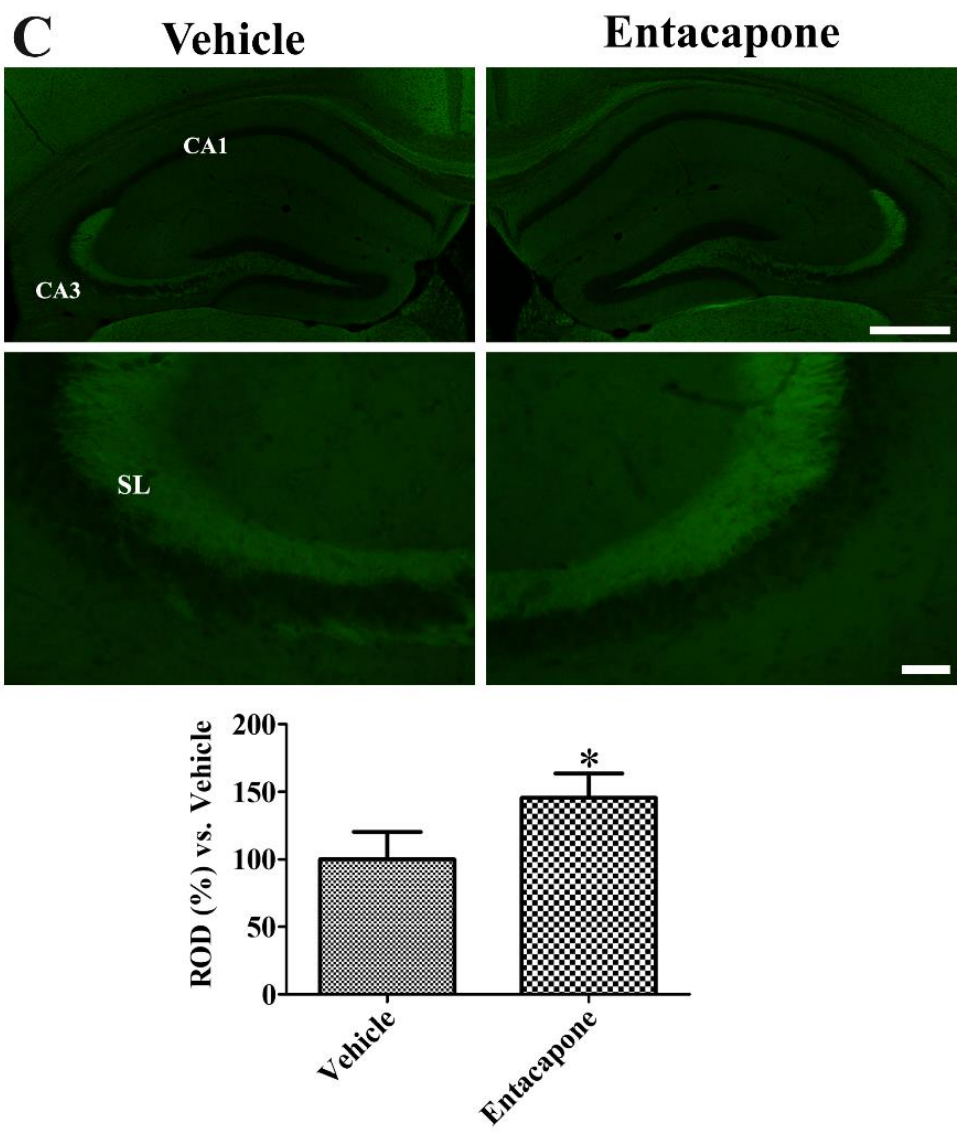

Figure 4. Munc18-1 expression in the hippocampus of vehicle- and entacapone-treated groups based on proteomic (A), western blot (B), and immunohistochemical (C) study. Munc18-1 was detected in a single spot. Munc18-1 protein levels were not significantly different between the hippocampi of vehicleand entacapone-treated groups, while protein levels are significantly increased in the synaptic vesicle fraction of entacapone-treated group compared to that in the control group. Relative optical density in the entacapone-treated group versus that in the vehicle-treated group is shown in percentages for western blot analysis ${ }^{*} p<0.05$, significantly different from the vehicle-treated group). Western blot assays were performed in at least triplicate and bar graph represents the mean \pm standard deviation. Munc18-1 immunoreactivity is observed in the stratum lucidum (SL) of CA3 region. Scale bar $=400 \mu \mathrm{m}$ (low magnification), $50 \mu \mathrm{m}$ (high magnification). Three sections, $150 \mu \mathrm{m}$ apart, are selected between 1.7 and $2.3 \mathrm{~mm}$ caudal to the bregma in each animal. Relative optical densities (ROD) are expressed as a percentage of the value of Munc18-1 protein levels and immunoreactivity in the vehicle-treated group ( $n=5$ in each group; ${ }^{*} p<0.05$, significantly different from the vehicle-treated group). The bars indicate the mean values \pm standard deviation.

\section{Discussion}

In the present study, we performed 2-DE and MALDI-TOF MS to elucidate the effects of entacapone on protein expression in the mouse hippocampus. We determined the identity of 76 protein spots, and the identified proteins were categorized into five groups.

\subsection{Vesicular Trafficking and Endocytosis}

Dynamin 1 was identified from three spots, and its expression level was markedly increased after entacapone administration. Dynamin 1, highly enriched in presynaptic terminals, is a GTP-binding protein, and is implicated in clathrin-mediated endocytosis [24]. In addition, the EH domain-containing protein 3 and adaptin ear-binding coat-associated protein 1 regulate endosomal transport and endocytosis $[25,26]$. Expressional changes in proteins belonging to this category support that COMT 
inhibition may influence the release of neurotransmitters in hippocampal neurons as well as the expression and elimination of synaptic molecules in the synaptic cleft.

\subsection{Cellular Signaling and Various Cellular Processes Including the Cell Cycle, Mitosis, and Differentiation}

Proteins categorized into this group are involved in various cellular processes, including signal transduction and regulation of the cell cycle. Transformation/transcription domain-associated protein is an adaptor protein with histone acetyltransferase activity and controls cell cycle progression in adult neurogenesis [27]. Additionally, it is implicated in the transcription of Myc, which plays important roles in the regulation of cell cycle, signaling, and cell growth [28]. Similarly, nuclear receptor-binding SET-domain protein 1 and guanine nucleotide-binding protein are implicated in cellular signaling $[29,30]$. In addition, COP9 signalosome complex subunit 4 and fizzy/cell division cycle 20 related 1 are key players in the control of the cell cycle, and they perform additional cellular functions [31,32]. Protein tyrosine phosphatase eliminates the phosphate groups from tyrosine residues of proteins, and acts as a key regulator of various cellular processes, such as the cell cycle, signal transduction, proliferation, and differentiation [33,34]. Tyrosine 3-monooxygenase/tryptophan 5-monooxygenase activation protein (14-3-3) is implicated in the mitogen-activated protein kinase pathway and regulates cell division and apoptosis [35]. In addition, the inhibition of 14-3-3 promotes

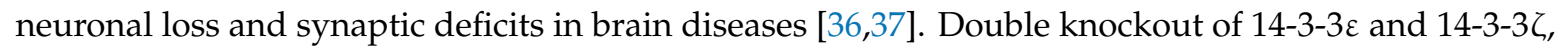
not its single knockout, significantly increases the proliferating cells during embryogenesis in mice [35]. Expressional changes in these proteins support the idea that entacapone treatment promotes the cell proliferation and neuroblast differentiation with consistent to our previous study that entacapone enriched the hippocampal functions and neurogenesis in mice [20].

\subsection{Cell Structure and Morphology}

Administration of entacapone induced expressional changes in proteins that are responsible for the construction of cell structure and the induction of cell migration. The expression of tubulin alpha and beta chains, which are major constituents of microtubules and the cytoskeleton, was changed, and the actin-associated proteins twinfilin 1 and actin-related protein 2/3 complex subunit 2 had increased expression levels. It has been reported that twinfilin 1 plays an essential role in the regulation of cytoskeletal structure [38], and actin-related protein $2 / 3$ complex subunit 2 is a regulator of cell migration in neural stem cell-derived oligodendrocytes in electric fields [39]. Depletion of twinfilin gene in flies showed defects in axonal growth of brain [40,41]. Expression of the dihydropyrimidinase-related proteins 1 and 2 was changed; these proteins are necessary for cytoskeleton remodeling, and they play a role in neuroprotection and synaptic plasticity [42,43]. In addition, the expression of spectrin, an actin crosslinking scaffold protein, and the expression of neurofilament light polypeptide was significantly changed [44]. Expressional changes in proteins belonging to this category support that COMT inhibition modulates protein related to cell structure and migration in the hippocampus, which promotes the hippocampal neurogenesis described in the previous study [20].

\subsection{Energy Metabolism}

After the administration of entacapone, the expression of proteins associated with carbohydrate and energy metabolism was significantly changed. Both alpha enolase, which was identified from two spots showing an increase upon entacapone treatment, as well as pyruvate kinase are glycolytic enzymes, and dihydrolipoamide S-acetyltransferase precursor participates in the metabolic pathway that links glycolysis and the tricarboxylic acid (TCA) cycle. Altered expression of proteins that regulate energy production might indicate that cellular functions with a high energy demand were initiated after entacapone treatment. In our previous study, we demonstrated that treatment with entacapone increased cell proliferation and neuroblast differentiation in the mouse hippocampus [20]. It has been reported that glucose metabolism and neurogenesis are closely related [45,46], and energy production is necessary not only for synaptic transmission but also for the proliferation, survival, 
and differentiation of neural stem cells [45]. We previously demonstrated that the neuronal type of glucose transporter plays an important role in postnatal development and neurogenesis in the hippocampus [47]. In addition, the treatment with phosphoglycerate mutase 1, a glycolytic enzyme, significantly increases the proliferation cells and neuroblasts in the hippocampus by promoting the phosphorylation of cAMP response element-binding protein [48]. A recent study showed entacapone directly bound to fat mass and obesity-associated gene (FTO) and inhibited the activity of FTO [49]. In addition, entacapone reduced the body weight and blood glucose concentration in obese mice [49]. In the present study, altered expression of proteins implicated in energy metabolism may increase the hippocampal neurogenesis as described in the previous study [20].

\subsection{Various Enzymatic Activities}

The proteins categorized into this group mediate various enzymatic reactions. In this category, proteins essential for glutamate synthesis were also identified. Glutamate is an excitatory neurotransmitter that plays an important role in the neuronal activation of the hippocampus [50,51].

Activation of dopaminergic neurotransmission induces long-term synaptic plasticity by facilitating glutamatergic NMDA receptors [52], and inhibition of dopamine-receptor signaling impaired passive avoidance memory and induction of long-term potentiation (LTP) in the hippocampus [53]. Glutamate receptors are closely involved in LTP-induced synaptic enhancement [54] and dopamine signal is required in the late LTP [55]. Glutamate dehydrogenase 1 plays a key role in the synthesis and degradation of glutamate, and is involved in hippocampal synapse formation [56,57]. Aspartate aminotransferase (AST) is closely involved in catalyzing glutamate formation and oxidation in brain [58], and administration of cytosolic AST increased axonal growth in cultured cortical neurons and enhanced memory function [59]. In the present study, the inhibition of COMT changes the metabolism of glutamate and this may be related to promotion of synaptic formation and axonal growth.

\subsection{Validation of Synaptic Vesicle Trafficking-Related Proteins}

In this study, we confirmed that dynamin 1 immunoreactivity was found in the presynaptic terminals of the hippocampus, and entacapone treatment significantly increased dynamin 1 expression in the hippocampus, which controls vesicular trafficking and endocytosis. Aged rodents show significantly lower levels of dynamin 1 in the hippocampus compared to adult rodents $[60,61]$. In addition, dynamin 1 expression is significantly decreased in an animal model of Alzheimer's disease $[62,63]$.

Munc18-1 is a member of the synaptic vesicle fusion protein complex, and has an important role in the exocytosis of neurotransmitters [64] and neurite outgrowth during development [65]. Munc18-1 interacts with the SNARE complex $[66,67]$ and facilitates the zippering of trans-SNARE complexes and promotes the SNARE-dependent membrane fusion in synaptosomes [68]. In contrast, knockdown of Munc18-1 shows abnormalities in cortical development [69] and diminished secretion of brain-derived neurotrophic factor [70]. In the present study, we observed Munc18-1 expression in the stratum lucidum in the hippocampus and its significant increase by entacapone treatment.

Synapsin I, a presynaptic marker protein, acts as a modulator of neurotransmitter release and synaptic vesicles [71], and inhibition of synapsin I decreased activity of both excitatory and inhibitory synapses in hippocampal cells [72]. Knockout of all synapsins showed lower serotonin levels in the hippocampus and behavioral dysfunctions [73]. Neurodegenerative diseases involve synaptic dysfunction, and synapsin I was significantly decreased in plasma neuronal-derived exosomes of Alzheimer's disease patients [74]. In the present study, we observed synapsin I immunoreactivity in the stratum lucidum of the hippocampal CA3 regions and mossy fibers in the dentate gyrus, and synapsin I expression was significantly elevated after entacapone treatment.

Neurotransmission is modulated by various factors such as presynaptic vesicular exocytosis, postsynaptic receptor expression, recycling of neurotransmitters, and activation of glial cells [75,76]. Administration of a COMT inhibitor activates dopaminergic neurotransmission in cerebral cortex [77]. 
In the hippocampus, dopaminergic innervation is well-detected and modulates hippocampal network and specific types of dopaminergic receptors are expressed in each hippocampal subregion $[78,79]$. In the present study, we confirmed expressional changes of the proteins which are closely related to vesicular trafficking in the hippocampal subregions following entacapone treatment. We are not sure that the proteins, which showed increased expression level in CA1, CA3, and dentate gyrus in this study, are expressed by hippocampal glutamatergic neurons, but increased level of vesicle trafficking-related proteins in the hippocampus is closely involved in synaptic plasticity and behavioral functions [80].

In conclusion, proteomic analysis indicated that entacapone induced changes in the expression of proteins involved in synaptic transmission, cellular processes, cellular signaling, the regulation of cytoskeletal structure, energy metabolism, and various other cellular reactions. In particular, increased vesicle trafficking-related proteins may be closely related to enhance synaptic plasticity and hippocampal functions.

Author Contributions: D.Y.Y., D.W.K. and I.K.H. conceived the projects. D.Y.Y., D.W.K. and I.K.H. were responsible for experimental design, data collection, and manuscript writing. D.Y.Y., H.Y.J., W.K. and K.R.H. performed the animal and immunohistochemical study. H.J.K. and D.W.K. conducted the biochemical analysis for study. S.M.N., J.Y.C. and Y.S.Y. performed data analysis and critical comments on the whole process of the study. All authors have read and agreed to the published version of the manuscript.

Funding: This work was supported by the National Research Foundation of Korea (NRF) grant funded by the Korea government (MSIP) (No. NRF-2018R1D1A1B07044543 and NRF-2019R1A2C1005440). In addition, this study was partially supported by the Research Institute for Veterinary Science of Seoul National University.

Conflicts of Interest: All authors have approved the manuscript for submission, and we have no conflict of interest to disclose.

\section{References}

1. Niethard, N.; Born, J. A backup of hippocampal spatial code outside the hippocampus? New light on systems memory consolidation. Neuron 2020, 106, 204-206. [CrossRef]

2. Kim, W.B.; Cho, J.H. Encoding of contextual fear memory in hippocampal-amygdala circuit. Nat. Commun. 2020, 11, 1382. [CrossRef] [PubMed]

3. Manning, C.E.; Eagle, A.L.; Kwiatkowski, C.C.; Achargui, R.; Woodworth, H.; Potter, E.; Ohnishi, Y.; Leinninger, G.M.; Robison, A.J. Hippocampal subgranular zone FosB expression is critical for neurogenesis and learning. Neuroscience 2019, 406, 225-233. [CrossRef]

4. Wood, E.R.; Mumby, D.G.; Pinel, J.P.; Phillips, A.G. Impaired object recognition memory in rats following ischemia-induced damage to the hippocampus. Behav. Neurosci. 1993, 107, 51-62. [CrossRef]

5. Cole, E.; Ziadé, J.; Simundic, A.; Mumby, D.G. Effects of perirhinal cortex and hippocampal lesions on rats' performance on two object-recognition tasks. Behav. Brain Res. 2020, 381, 112450. [CrossRef] [PubMed]

6. Jessberger, S.; Clark, R.E.; Broadbent, N.J.; Clemenson, G.D., Jr.; Consiglio, A.; Lie, D.C.; Squire, L.R.; Gage, F.H. Dentate gyrus-specific knockdown of adult neurogenesis impairs spatial and object recognition memory in adult rats. Learn. Mem. 2009, 16, 147-154. [CrossRef] [PubMed]

7. Ohara, S.; Sato, S.; Tsutsui, K.; Witter, M.P.; Iijima, T. Organization of multisynaptic inputs to the dorsal and ventral dentate gyrus: Retrograde trans-synaptic tracing with rabies virus vector in the rat. PLoS ONE 2013, 8, e78928. [CrossRef]

8. Kempadoo, K.A.; Mosharov, E.V.; Choi, S.J.; Sulzer, D.; Kandel, E.R. Dopamine release from the locus coeruleus to the dorsal hippocampus promotes spatial learning and memory. Proc. Natl. Acad. Sci. USA 2016, 113, 14835-14840. [CrossRef]

9. Strehl, A.; Galanis, C.; Radic, T.; Schwarzacher, S.W.; Deller, T.; Vlachos, A. Dopamine modulates homeostatic excitatory synaptic plasticity of immature dentate granule cells in entorhino-hippocampal slice cultures. Front. Mol. Neurosci. 2018, 11, 303. [CrossRef]

10. Stubbendorff, C.; Stevenson, C.W. Dopamine regulation of contextual fear and associated neural circuit function. Eur. J. Neurosci. 2020. [CrossRef]

11. Müller, T. Entacapone. Expert Opin. Drug Metab. Toxicol. 2010, 6, 983-993. [CrossRef] 
12. Bertolini, F.; Novaroli, L.; Carrupt, P.A.; Reist, M. Novel screening assay for antioxidant protection against peroxyl radical-induced loss of protein function. J. Pharm. Sci. 2007, 96, 2931-2944. [CrossRef]

13. Chen, A.Y.; Lü, J.M.; Yao, Q.; Chen, C. Entacapone is an antioxidant more potent than vitamin C and vitamin E for scavenging of hypochlorous acid and peroxynitrite, and the inhibition of oxidative stress-induced cell death. Med. Sci. Monit. 2016, 22, 687-696. [CrossRef]

14. Di Giovanni, S.; Eleuteri, S.; Paleologou, K.E.; Yin, G.; Zweckstetter, M.; Carrupt, P.A.; Lashuel, H.A. Entacapone and tolcapone, two catechol O-methyltransferase inhibitors, block fibril formation of alpha-synuclein and beta-amyloid and protect against amyloid-induced toxicity. J. Biol. Chem. 2010, 285, 14941-14954. [CrossRef]

15. Karlsson, M.; Wikberg, T. Liquid chromatographic determination of a new catechol-O-methyltransferase inhibitor, entacapone, and its Z-isomer in human plasma and urine. J. Pharm. Biomed. Anal. 1992, 10, 593-600. [CrossRef]

16. Heikkinen, H.; Varhe, A.; Laine, T.; Puttonen, J.; Kela, M.; Kaakkola, S.; Reinikainen, K. Entacapone improves the availability of L-dopa in plasma by decreasing its peripheral metabolism independent of L-dopa/carbidopa dose. Br. J. Clin. Pharmacol. 2002, 54, 363-371. [CrossRef]

17. Brannan, T.; Prikhojan, A.; Yahr, M.D. Peripheral and central inhibitors of catechol-O-methyl transferase: Effects on liver and brain COMT activity and L-DOPA metabolism. J. Neural Transm. 1997, 104, 77-87. [CrossRef]

18. Kaakkola, S.; Wurtman, R.J. Effects of COMT inhibitors on striatal dopamine metabolism: A microdialysis study. Brain Res. 1992, 587, 241-249. [CrossRef]

19. Polak, P.E.; Lin, S.X.; Pelligrino, D.; Feinstein, D.L. The blood-brain barrier-permeable catechol-O-methyltransferase inhibitor dinitrocatechol suppresses experimental autoimmune encephalomyelitis. J. Neuroimmunol. 2014, 276, 135-141. [CrossRef]

20. Yoo, D.Y.; Jung, H.Y.; Kim, W.; Hahn, K.R.; Kwon, H.J.; Nam, S.M.; Chung, J.Y.; Yoon, Y.S.; Kim, D.W.; Hwang, I.K. Entacapone increases proliferating cells and immature neurons in the mouse hippocampus via up-regulation of the BDNF/TrkB/pCREB pathway. Neural Reg. Res. 2021, 16, 1005-1010.

21. Yoo, D.Y.; Cho, S.B.; Jung, H.Y.; Kim, W.; Choi, G.M.; Won, M.H.; Kim, D.W.; Hwang, I.K.; Choi, S.Y.; Moon, S.M. Tat-protein disulfide-isomerase A3: A possible candidate for preventing ischemic damage in the spinal cord. Cell Death Dis. 2017, 8, e3075. [CrossRef]

22. Jung, H.Y.; Kim, W.; Hahn, K.R.; Kwon, H.J.; Nam, S.M.; Chung, J.Y.; Yoon, Y.S.; Kim, D.W.; Yoo, D.Y.; Hwang, I.K. Effects of pyridoxine deficiency on hippocampal function and its possible association with V-type proton ATPase subunit B2 and heat shock cognate protein 70. Cells 2020, 9, 1067. [CrossRef]

23. Paxinos, G.; Franklin, K.B.J. The Mouse Brain in Stereotaxic Coordinates; Academic Press: San Diego, CA, USA, 2001.

24. Reis, C.R.; Chen, P.H.; Bendris, N.; Schmid, S.L. TRAIL-death receptor endocytosis and apoptosis are selectively regulated by dynamin-1 activation. Proc. Natl. Acad. Sci. USA 2017, 114, 504-509. [CrossRef]

25. Bahl, K.; Xie, S.; Spagnol, G.; Sorgen, P.; Naslavsky, N.; Caplan, S. EHD3 protein is required for tubular recycling endosome stabilization, and an asparagine-glutamic acid residue pair within its Eps15 homology (EH) domain dictates its selective binding to NPF peptides. J. Biol. Chem. 2016, 291, 13465-13478. [CrossRef]

26. Ritter, B.; Philie, J.; Girard, M.; Tung, E.C.; Blondeau, F.; McPherson, P.S. Identification of a family of endocytic proteins that define a new alpha-adaptin ear-binding motif. EMBO Rep. 2003, 4, 1089-1095. [CrossRef]

27. Tapias, A.; Zhou, Z.W.; Shi, Y.; Chong, Z.; Wang, P.; Groth, M.; Platzer, M.; Huttner, W.; Herceg, Z.; Yang, Y.G.; et al. Trrap-dependent histone acetylation specifically regulates cell-cycle gene transcription to control neural progenitor fate decisions. Cell Stem Cell 2014, 14, 632-643. [CrossRef]

28. Zinin, N.; Adameyko, I.; Wilhelm, M.; Fritz, N.; Uhlén, P.; Ernfors, P.; Henriksson, M.A. MYC proteins promote neuronal differentiation by controlling the mode of progenitor cell division. EMBO Rep. 2014, 15, 383-391. [CrossRef]

29. Lucio-Eterovic, A.K.; Singh, M.M.; Gardner, J.E.; Veerappan, C.S.; Rice, J.C.; Carpenter, P.B. Role for the nuclear receptor-binding SET domain protein 1 (NSD1) methyltransferase in coordinating lysine 36 methylation at histone 3 with RNA polymerase II function. Proc. Natl. Acad. Sci. USA 2010, 107, 16952-16957. [CrossRef]

30. Huang, Y.; Thathiah, A. Regulation of neuronal communication by G protein-coupled receptors. FEBS Lett. 2015, 589, 1607-1619. [CrossRef] [PubMed] 
31. Eguren, M.; Porlan, E.; Manchado, E.; García-Higuera, I.; Cañamero, M.; Fariñas, I.; Malumbres, M. The APC/C cofactor Cdh1 prevents replicative stress and p53-dependent cell death in neural progenitors. Nat. Commun. 2013, 4, 2880. [CrossRef] [PubMed]

32. Betsch, L.; Boltz, V.; Brioudes, F.; Pontier, G.; Girard, V.; Savarin, J.; Wipperman, B.; Chambrier, P.; Tissot, N.; Benhamed, M.; et al. TCTP and CSN4 control cell cycle progression and development by regulating CULLIN1 neddylation in plants and animals. PLoS Genet. 2019, 15, e1007899. [CrossRef] [PubMed]

33. Kim, S.Y.; Oh, M.; Lee, K.S.; Kim, W.K.; Oh, K.J.; Lee, S.C.; Bae, K.H.; Han, B.S. Profiling analysis of protein tyrosine phosphatases during neuronal differentiation. Neurosci. Lett. 2016, 612, 219-224. [CrossRef] [PubMed]

34. Tomita, H.; Cornejo, F.; Aranda-Pino, B.; Woodard, C.L.; Rioseco, C.C.; Neel, B.G.; Alvarez, A.R.; Kaplan, D.R.; Miller, F.D.; Cancino, G.I. The protein tyrosine phosphatase receptor delta regulates developmental neurogenesis. Cell Rep. 2020, 30, 215-228.e5. [CrossRef] [PubMed]

35. Cornell, B.; Toyo-Oka, K. 14-3-3 Proteins in brain development: Neurogenesis, neuronal migration and neuromorphogenesis. Front. Mol. Neurosci. 2017, 10, 318. [CrossRef] [PubMed]

36. Ding, H.; Underwood, R.; Lavalley, N.; Yacoubian, T.A. 14-3-3 inhibition promotes dopaminergic neuron loss and 14-3-30 overexpression promotes recovery in the MPTP mouse model of Parkinson's disease. Neuroscience 2015, 307, 73-82. [CrossRef] [PubMed]

37. Foote, M.; Qiao, H.; Graham, K.; Wu, Y.; Zhou, Y. Inhibition of 14-3-3 proteins leads to Schizophrenia-related behavioral phenotypes and synaptic defects in mice. Biol. Psychiatry 2015, 78, 386-395. [CrossRef]

38. Takács-Kollár, V.; Nyitrai, M.; Hild, G. The effect of mouse twinfilin-1 on the structure and dynamics of monomeric actin. Biochim. Biophys. Acta 2016, 1864, 840-846. [CrossRef]

39. Li, Y.; Wang, P.S.; Lucas, G.; Li, R.; Yao, L. ARP2/3 complex is required for directional migration of neural stem cell-derived oligodendrocyte precursors in electric fields. Stem Cell Res. Ther. 2015, 6, 41. [CrossRef]

40. Wang, D.; Zhang, L.; Zhao, G.; Wahlström, G.; Heino, T.I.; Chen, J.; Zhang, Y.Q. Drosophila twinfilin is required for cell migration and synaptic endocytosis. J. Cell Sci. 2010, 123, 1546-1556. [CrossRef]

41. Wahlström, G.; Vartiainen, M.; Yamamoto, L.; Mattila, P.K.; Lappalainen, P.; Heino, T.I. Twinfilin is required for actin-dependent developmental processes in Drosophila. J. Cell Biol. 2001, 155, 787-796. [CrossRef]

42. Takaya, R.; Nagai, J.; Piao, W.; Niisato, E.; Nakabayashi, T.; Yamazaki, Y.; Nakamura, F.; Yamashita, N.; Kolattukudy, P.; Goshima, Y.; et al. CRMP1 and CRMP4 are required for proper orientation of dendrites of cerebral pyramidal neurons in the developing mouse brain. Brain Res. 2017, 1655, 161-167. [CrossRef] [PubMed]

43. Wu, Z.; Wang, G.; Xiao, L.; Wei, Y.; Wang, H.; Zhou, L.; Sun, L. Resilience in the LPS-induced acute depressive-like behaviors: Increase of CRMP2 neuroprotection and microtubule dynamics in hippocampus. Brain Res. Bull. 2020, 162, 261-270. [CrossRef] [PubMed]

44. Frappier, T.; Derancourt, J.; Pradel, L.A. Actin and neurofilament binding domain of brain spectrin beta subunit. Eur. J. Biochem. 1992, 205, 85-91. [CrossRef] [PubMed]

45. Rafalski, V.A.; Brunet, A. Energy metabolism in adult neural stem cell fate. Prog. Neurobiol. 2011, 93, $182-203$. [CrossRef] [PubMed]

46. Chen, X.; Shen, W.B.; Yang, P.; Dong, D.; Sun, W.; Yang, P. High glucose inhibits neural stem cell differentiation through oxidative stress and endoplasmic reticulum stress. Stem Cells Dev. 2018, 27, 745-755. [CrossRef]

47. Jung, H.Y.; Yim, H.S.; Yoo, D.Y.; Kim, J.W.; Chung, J.Y.; Seong, J.K.; Yoon, Y.S.; Kim, D.W.; Hwang, I.K. Postnatal changes in glucose transporter 3 expression in the dentate gyrus of the C57BL/6 mouse model. Lab. Anim. Res. 2016, 32, 1-7. [CrossRef]

48. Jung, H.Y.; Kwon, H.J.; Kim, W.; Nam, S.M.; Kim, J.W.; Hahn, K.R.; Yoo, D.Y.; Won, M.H.; Yoon, Y.S.; Kim, D.W.; et al. Phosphoglycerate mutase 1 promotes cell proliferation and neuroblast differentiation in the dentate gyrus by facilitating the phosphorylation of cAMP response element-binding protein. Neurochem. Res. 2019, 44, 323-332. [CrossRef]

49. Peng, S.; Xiao, W.; Ju, D.; Sun, B.; Hou, N.; Liu, Q.; Wang, Y.; Zhao, H.; Gao, C.; Zhang, S.; et al. Identification of entacapone as a chemical inhibitor of FTO mediating metabolic regulation through FOXO1. Sci. Transl. Med. 2019, 11, eaau7116. [CrossRef]

50. Adeniyi, P.A.; Shrestha, A.; Ogundele, O.M. Distribution of VTA glutamate and dopamine terminals, and their significance in CA1 neural network activity. Neuroscience 2020, 446, 171-198. [CrossRef] 
51. Barnes, J.R.; Mukherjee, B.; Rogers, B.C.; Nafar, F.; Gosse, M.; Parsons, M.P. The relationship between glutamate dynamics and activity-dependent synaptic plasticity. J. Neurosci. 2020, 40, 2793-2807. [CrossRef]

52. Palacios-Filardo, J.; Mellor, J.R. Neuromodulation of hippocampal long-term synaptic plasticity. Curr. Opin. Neurobiol. 2019, 54, 37-43. [CrossRef] [PubMed]

53. Broussard, J.I.; Yang, K.; Levine, A.T.; Tsetsenis, T.; Jenson, D.; Cao, F.; Garcia, I.; Arenkiel, B.R.; Zhou, F.M.; De Biasi, M.; et al. Dopamine regulates aversive contextual learning and associated in vivo synaptic plasticity in the hippocampus. Cell Rep. 2016, 14, 1930-1939. [CrossRef] [PubMed]

54. Tominaga-Yoshino, K.; Urakubo, T.; Ueno, Y.; Kawaai, K.; Saito, S.; Tashiro, T.; Ogura, A. Transient appearance of $\mathrm{Ca}^{2+}$-permeable AMPA receptors is crucial for the production of repetitive LTP-induced synaptic enhancement (RISE) in cultured hippocampal slices. Hippocampus 2020, 30, 763-769. [CrossRef] [PubMed]

55. Lisman, J. Glutamatergic synapses are structurally and biochemically complex because of multiple plasticity processes: Long-term potentiation, long-term depression, short-term potentiation and scaling. Philos. Trans. R. Soc. Lond. B. Biol. Sci. 2017, 372, 20160260. [CrossRef] [PubMed]

56. Michaelis, E.K.; Wang, X.; Pal, R.; Bao, X.; Hascup, K.N.; Wang, Y.; Wang, W.T.; Hui, D.; Agbas, A.; Choi, I.Y.; et al. Neuronal Glud1 (glutamate dehydrogenase 1) over-expressing mice: Increased glutamate formation and synaptic release, loss of synaptic activity, and adaptive changes in genomic expression. Neurochem. Int. 2011, 59, 473-481. [CrossRef]

57. Lander, S.S.; Chornyy, S.; Safory, H.; Gross, A.; Wolosker, H.; Gaisler-Salomon, I. Glutamate dehydrogenase deficiency disrupts glutamate homeostasis in hippocampus and prefrontal cortex and impairs recognition memory. Genes Brain Behav. 2020, 19, e12636. [CrossRef]

58. Hertz, L.; Rothman, D.L. Glutamine-Glutamate Cycle Flux Is Similar in Cultured Astrocytes and Brain and Both Glutamate Production and Oxidation Are Mainly Catalyzed by Aspartate Aminotransferase. Biol. 2017, 6, 17. [CrossRef]

59. Kobayashi, R.; Tohda, C. Extracellular cytosolic aspartate aminotransferase promotes axonal growth and object recognition memory. Neurochem. Res. 2017, 42, 3465-3473. [CrossRef]

60. VanGuilder, H.D.; Farley, J.A.; Yan, H.; Van Kirk, C.A.; Mitschelen, M.; Sonntag, W.E.; Freeman, W.M. Hippocampal dysregulation of synaptic plasticity-associated proteins with age-related cognitive decline. Neurobiol. Dis. 2011, 43, 201-212. [CrossRef]

61. Yoo, D.Y.; Jung, H.Y.; Kim, J.W.; Yim, H.S.; Kim, D.W.; Nam, H.; Suh, J.G.; Choi, J.H.; Won, M.H.; Yoon, Y.S.; et al. Reduction of dynamin 1 in the hippocampus of aged mice is associated with the decline in hippocampal-dependent memory. Mol. Med. Rep. 2016, 14, 4755-4760. [CrossRef]

62. Kelly, B.L.; Vassar, R.; Ferreira, A. Beta-amyloid-induced dynamin 1 depletion in hippocampal neurons. A potential mechanism for early cognitive decline in Alzheimer disease. J. Biol. Chem. 2005, 280, 31746-31753. [CrossRef]

63. Ciavardelli, D.; Silvestri, E.; Del Viscovo, A.; Bomba, M.; De Gregorio, D.; Moreno, M.; Di Ilio, C.; Goglia, F.; Canzoniero, L.M.; Sensi, S.L. Alterations of brain and cerebellar proteomes linked to A $\beta$ and tau pathology in a female triple-transgenic murine model of Alzheimer's disease. Cell Death Dis. 2010, 1, e90. [CrossRef] [PubMed]

64. Zilly, F.E.; Sørensen, J.B.; Jahn, R.; Lang, T. Munc18-bound syntaxin readily forms SNARE complexes with synaptobrevin in native plasma membranes. PLoS Biol. 2006, 4, e330. [CrossRef] [PubMed]

65. Broeke, J.H.; Roelandse, M.; Luteijn, M.J.; Boiko, T.; Matus, A.; Toonen, R.F.; Verhage, M. Munc18 and Munc13 regulate early neurite outgrowth. Biol. Cell 2010, 102, 479-488. [CrossRef]

66. Rizo, J.; Südhof, T.C. The membrane fusion enigma: SNAREs, Sec1/Munc18 proteins, and their accomplices-guilty as charged? Annu. Rev. Cell Dev. Biol. 2012, 28, 279-308. [CrossRef] [PubMed]

67. Daraio, T.; Valladolid-Acebes, I.; Brismar, K.; Bark, C. SNAP-25a and SNAP-25b differently mediate interactions with Munc18-1 and G $\beta \gamma$ subunits. Neurosci. Lett. 2018, 674, 75-80. [CrossRef] [PubMed]

68. Shen, C.; Rathore, S.S.; Yu, H.; Gulbranson, D.R.; Hua, R.; Zhang, C.; Schoppa, N.E.; Shen, J. The trans-SNARE-regulating function of Munc18-1 is essential to synaptic exocytosis. Nat. Commun. 2015, 6, 8852. [CrossRef]

69. Hamada, N.; Iwamoto, I.; Tabata, H.; Nagata, K.I. MUNC18-1 gene abnormalities are involved in neurodevelopmental disorders through defective cortical architecture during brain development. Acta Neuropathol. Commun. 2017, 5, 92. [CrossRef] 
70. Lee, Y.I.; Kim, Y.G.; Pyeon, H.J.; Ahn, J.C.; Logan, S.; Orock, A.; Joo, K.M.; Lőrincz, A.; Deák, F. Dysregulation of the SNARE-binding protein Munc18-1 impairs BDNF secretion and synaptic neurotransmission: A novel interventional target to protect the aging brain. Geroscience 2019, 41, 109-123. [CrossRef]

71. Bykhovskaia, M. Synapsin regulation of vesicle organization and functional pools. Semin. Cell Dev. Biol. 2011, 22, 387-392. [CrossRef]

72. Rocchi, A.; Sacchetti, S.; De Fusco, A.; Giovedi, S.; Parisi, B.; Cesca, F.; Höltje, M.; Ruprecht, K.; Ahnert-Hilger, G.; Benfenati, F. Autoantibodies to synapsin I sequestrate synapsin I and alter synaptic function. Cell Death Dis. 2019, 10, 864. [CrossRef] [PubMed]

73. Mazzocco, M.T.; Guarnieri, F.C.; Monzani, E.; Benfenati, F.; Valtorta, F.; Comai, S. Dysfunction of the serotonergic system in the brain of synapsin triple knockout mice is associated with behavioral abnormalities resembling synapsin-related human pathologies. Prog. Neuropsychopharmacol. Biol. Psychiatry 2020, 12, 110135.

74. Goetzl, E.J.; Kapogiannis, D.; Schwartz, J.B.; Lobach, I.V.; Goetzl, L.; Abner, E.L.; Jicha, G.A.; Karydas, A.M.; Boxer, A.; Miller, B.L. Decreased synaptic proteins in neuronal exosomes of frontotemporal dementia and Alzheimer's disease. FASEB J. 2016, 30, 4141-4148. [CrossRef] [PubMed]

75. Pascual, O.; Achour, S.B.; Rostaing, P.; Triller, A.; Bessis, A. Microglia activation triggers astrocyte-mediated modulation of excitatory neurotransmission. Proc. Natl. Acad. Sci. USA 2012, 109, 197-205. [CrossRef]

76. Cockerham, R.; Liu, S.; Cachope, R.; Kiyokage, E.; Cheer, J.F.; Shipley Puche, A.C. Subsecond regulation of synaptically released dopamine by COMT in the olfactory bulb. J. Neurosci. 2016, 36, 7779-7785. [CrossRef] [PubMed]

77. Lapish, C.; Ahn, S.; Evangelista, L.; So, K.; Seamans, J.; Phillips, A. Tolcapone enhances food-evoked dopamine efflux and executive memory processes mediated by the rat prefrontal cortex. Psychopharmacology 2009, 202, 521-530. [CrossRef]

78. Edelmann, E.; Lessmann, V. Dopaminergic innervation and modulation of hippocampal networks. Cell Tissue Res. 2018, 373, 711-727. [CrossRef]

79. Hernández, V.S.; Luquín, S.; Jáuregui-Huerta, F.; Corona-Morales, A.A.; Medina, M.P.; Ruíz-Velasco, S.; Zhang, L. Dopamine receptor dysregulation in hippocampus of aged rats underlies chronic pulsatile L-Dopa treatment induced cognitive and emotional alterations. Neuropharmacology 2014, 82, 88-100. [CrossRef]

80. Popova, D.; Castren, E.; Taira, T. Chronic fluoxetine administration enhances synaptic plasticity and increases functional dynamics in hippocampal CA3-CA1 synapses. Neuropharmacology 2017, 126, 250-256. [CrossRef]

Publisher's Note: MDPI stays neutral with regard to jurisdictional claims in published maps and institutional affiliations.

(C) 2020 by the authors. Licensee MDPI, Basel, Switzerland. This article is an open access article distributed under the terms and conditions of the Creative Commons Attribution (CC BY) license (http://creativecommons.org/licenses/by/4.0/). 